may well imagine we have come into a vast cathedral from whose roof there echoes to us the sound of the voice of one of our brethren of the centuries B.C., of whom Addison tells as that he called his treatise on anatomy "a hymn to the Supreme Being.'

The Continuity of Lifa.

6. It is here, perhaps, that we find the most thrilling of all the transformations that have taken place in the thought of those who have the gift, the right, and the responsibility to think. Man, "servant and interpreter of Nature," soaring among the stars to analyze their elements, or searching out the secrets of the atom and the cell, has found himself an item in a social cosmos, subject through all its bounds to the reign of law. A composite being, formed out of the dust, yet capable of communing with the Spirit, who has not, at any time, anywhere, among any people, left Himself without a witness, he finds that there is nothing alien to him in all the universe. Standing on the summits of creation and summing up in himself the last results of the long processes of evolution, he looks to find his ultimate home in One who is, from everlasting to everlasting, God. He is the more encouraged to such lofty ideal when he traces his genealogy back-away back to where the foundations of the earth were laid. His mind reflects the mind that fashioned its materials, and somewhere among the ions and the biophors, where he can scarcely tell whether the ion is not already instinct with more than electricity, or the biophor holds less than life, he sees the narrow fissure between the unseen and the seen, between the not-living and the living, bridged by a kind of virgin-birth with repetitions of which in some form natural science wil make him familiar as he traces the various stages in his own evolution. For parthenogenesis is found not only among the early forms of life, where the distinction between plant and animal is hard to decipher, and where the non-sentient is passing into the sentient, but again and again in transition pages in the evolution story where we see changes taking place in the types with which the record has been written.

The Individuad Liek.

7. Each individual from out the race is set before himsel distinct from all, yet consociate with all. Our first sight of our individual selves as we emerge upon the field of being is as a microscopic speck of protoplasm. It may not differ in appeurance or in composition from such another epeck as would grow into a creature of another kind. It may resemble the creatures we call protozoa, because in the school of life they have never gone beyond the alphabet. But it possesses the attribute common to everything that lives of taking into itself what it finds needful from its surrounding elements. Let it respond to the impulses, the claims, of its environment and use the matter it assimilates to grow or multiply, and it will live on; it will develop and reproduce according to its kind. Let it at any stage of its history begin to assimilate for assimilation's sake, and it is ready to die; or worse, it may degenerate. The germ-plasm seen through the microscop was one of a cityful of more than seventy thousand primordia ova, only four or five of which are selected to pass through evolutionary processes that recapitulate at various stages the history of their pre-human genealogy before they come to claim a place in a nation's register. Each of the four, as his evolution still progresses, will find after he has come to him self, and so long as his self-consciousness abides, that the material part of him is subject to incessant change. He is continually putting off his mortal vesture and replacing it with a better-fitting garb. The seven pounds weight of matter that was laid in the infant balance passes all away, every atom of it; and if he reach the Mosaic term of three-score pears and ten he is told, though he may not have noticed it, that he has ten times changed the fabric of the frame his spirit tenants. If he be wise, he will long ere then have pondired how the latest fashion of his vestment will be put offwhether in one way or another.

"Not THAT I WOULD BE UNCLOTHED."

In one way. One of the heroes of my opening manhood one of the most lovable of men, was so great a naturalist that when he died in his prime Sydney Dobell wrote me a note suggesting these four lines for his epitaph:

He courted Nature for his mistress; wooed her so He won her, till, by love made bold,

She showed him more than mortal man should knowThen slew him, lest her secrets should bo told.

A few hours before his passing a friend came to his bedside

and asked him, "How do you feel now?" and was answered, "I feel just like a creature carried down a river."

In that way, or in this. When I went to practise in Glasgow, the man at the top of the profession, though still in middle life, had resigned the Chair of the Practice of Physic in the Andersonian University, being somewhat delicate in health, and had reached that busy eminence where his fellow-citizens could not let their sick friends die till he had seen them, and where his professional brethren were not quite satisfied that medicine had done its last and best till they had had a consultation with him. When Dr. Andrew Anderson was on his deathbed, one of his fellow-elders who was also il) sent to inquire how it fared with him. "Tell him," said Dr. Anderson, borrowing from Hopeful in the Pilgrim's Progress, "I' $m$ in the very middle of the river, but $I$ feel the bottom. and it is good."

It may chance that some July day, far down the century, when I have been long in the ether, one or other of you will talk with child or grandchild of the years when the century was young. Among its unforgotten scenes there will rise before your mind the memory of the day when at last you burst the chrysalis shell of pupillage to lift free wings into the azure. You will recall the unusual concurrence of the simultaneous leave-taking of the University by the graduates and their promoter. "We came away," you will say, "a goodly company, all together, through the gateway that leads to the rosy dawn. He passed out, all alone, through the door that looks to the sunset and evening star. He was an old man like me," I forehear you say. "Not a great man, he had been a friend of great men, and came out of a great time in the nineteenth century 'when there was mid-sea and the mighty things,' and it looked to the men of his generation as if old things had all passed away and a new world begun. And he told us that the great lesson he had learned on his way through life was the same that the disciple who leaned on Jesus's breast at supper taught to the fathers, the young men, and the little children of his time when he said, "The world passeth away, and the lust thereof; but he that doeth the will of God abideth for ever." Farewell.

\title{
ON THE BEHAVIOUR OF LEUCOCYTES IN MALIGNANT GROWTHB.
}

J. B. FARMER, F.R.S., Professor of Botany, Royal College of Science, London. BY

AN D C. E. WALKER, F.L.S.

In the present paper it is proposed to give an account of observations relating to the peculiar behaviour of leucocytes in very early examples of carcinoma occurring in various parts of the human body.

The phenomena described appear to be mainly-if not entirely-restricted to cancer in its earliest stages and not to occur in older growths, in metastases, or in grafts introduced into other individuals.

Our observations at the present moment refer more especially to (1) a small primary rectal tumour, (2) an early case of chimney-8weep's cancer, and (3) an early epithelioma of the penis. In all of these the essential details in relation to the behaviour of the leucocytes are identical and suggest that we are dealing with cytological phenomena peculiar to the earliest phases of the transmutation of normal tissue cello into cancerous elements.

It has frequently been noticed that around areas that are becoming cancerous there exists a marked activity among the leucocytes, and the fact that cells in a cancerous area may contain leucocytic bodies within their cytoplasm has frequently been observed. The latter cases have been regarded generally either as phagocytic invasion of the leucocytes, or as an indication that the cancer cells have assumed a phagocytic character with respect to the leucocytes. The results of the present investigations are not in accordance with either of these views.

It was found in the rectal carcinoma above mentioned, for example (a growth that had hardly attained the size of a bean), that there was a very distinct zone of transition from the normal to the cancerous elements around the periphery of the tumour ; that is to say, a zone in which it was possible to pass, within the thickness of a few cells and almost insensibly, from elements that were merely actively dividing in the mucous 
layer, to cells that had assumed most markedly malignant characters.

In this and other cases that we have examined, we were irresistibly driven to the conclusion that the growth had not originated from a single cell, or even from a few cells, but was being evolved by the direct conversion of a great many elements definitely functioning as mucous cells into those of a truly malignant type.

Immediately within this outer zone of the tumour the leucocytic crowding was most strikingly apparent, and in a number of cells it was easy to discern the presence of leucocytes which had invaded the cytoplasm of the epithelium where they stained readily as an inclusion. This phenomenon did not occur in the adjacent healthy tissue, and we have been unable ourselves to trace it in inflammatory lesions produced by artificial means.

But the most important, as well as the most singular fexture about the intrusion of the leucocytes into the tumour cells lies in the fact that neither the leucocyte nor the invaded tissue cell appears to be injuriously affected. Neither appear to be eventually destroyed, and it was soon found that many epithelial cells which were in stages of activedivision contained leucocytes that had been engulfed in their cytoplasm. In many instances it was found, moreover, that while the tissue cell was dividing mitotically the included leucocyte was also dividing in a similar manner, and at the same time. Both nuclei either passed through their mitotic evolutions upon separate spindles, or the spindle figures were confused, as is ordinarily the case in the first cleavage of the ovum. It is, we think, clear, from the observations just recorded, that a mixture of the chromosomes derived from the leucocyte and tissue cell respectively is distributed between the daughter nuclei resulting from the mitosis. In this way a complete disturbance of the normal chromosome constituents of the cell will be effected, and the distribution must be of a qualitative as well as of a quantitative character.

It may be well to indicate that if this process be compared to fertilization, there exists an important difference between true gametes and the cells concerned in this anomalous fusion. In the former (gametes) we are dealing with nuclei that have passed through the phases of reduction (maiosis), whereas there is no evidence at present to show that this is $\left.s_{1}\right)$ in the case now under consideration. What its relation to the ultimate reduction that does occur in neoplastic cells may be, is a subject for further investigation.

It may be pinted out that the iusion here described in no way corresponcs with that union which has been stated to orcur between the definite cancerous cells of certain neoplastic graits.

In bringing this brief communication to a close, we desire t) express our indebtedness to the Imperial Cancer Research Fand for a grant in aid of our investigations.

Baquests to Medical Charities.-Migs Margaret Baker, of Brightın, who died on June i ith, left $£ 150$ to the Zenana Medical Mission, $£ 50$ to the Homoeopathic 1)ispensary, Richmond Road, Brignton, $£$ ioo to the Royal Hospital for Incurables. Putney, $£ 20$ to the Royal Alexandra Hospital for Sick Children, and $\delta 20$ to the Sussex County Hospital.

Decline of Typhoid Mortality in Chicago.-A recent bulletin of the Health Department of Chicago issued by Dr A. R. Reynolds, Health Commissioner, announces a further reduction in the typhoid death-rate. It will be remembered that in 189 i typhoid fever was extremely prevaleut in Chicago. Indeed that city had the highest typhoid death-rate of any large city in the world, namely, 17.38 per 10 000 of the population. The Commissioner is able to report a rate of 193 per 10000 for 1904. This marked reduction through steady gradations of decline is stated to be due to the recent alterations in the water supply. At the close of 1888 there were but three sewers discharging into Lake Michigan. Subsequently these were increased to 29 , and the city water supply was taken from the lake at distances varying from $1,400 \mathrm{ft}$. to 2 miles from shore. With the increase of sewage iin the shore waters ty phoid increased, so that the 375 typhoid deaths of 1888 were swollen to 1,997 in 189r. It was then, on the eve of the "World's Fair," that the matter was grappled with. Tunnels were extended and shore intakes abandoned, and this policy has been continued, with the result that at present all intakes are beyond the zone of sewage pollutions "under usual conditions." Other similar improvements have been made. At present the mortal statistics of Chicago appear to be favourable, and the death-rate for the week ended May 27th was II 89 per $1, \infty 00$.
SEVENTY-THIRD ANNUAL MEETING OF THE

\section{Britist) Attedical Assocíation.}

Held at Leicester July 24th, 25th, 26th, 27th, and 28th, 1905.

PROCEEDINGS OF SECTIONS.

SECTION OF NAVY, ARMY, AND

Surgeon-Lieutenant-Colonel HenRy Walter Kiallmark, M.R.C.S., President.

\section{PRESIDENT'S INTRODUCTORY REMARKS.}

Is opening the proceedings of the Section, it is my first duty and $p$ earure to thank those members who are attending, and to express a hope that they will take part in the discussion, which should be highly interesting and instructive.

The papers to be brought before you are, as you will observe, well worthy of your attention. Your Committee have thought that it would be well to take the navy papers to-day, the army papers to-morrow, and the ambulance papers on Friday. Under all these headings, much of professional and national interest has arisen since our last meeting.

The Russo. Japanese war is such a mine of experience and knowledge, and although the official reports from both sides are not yet issued, sufficient has been published to enable us to realize the almost perfect manner in which the Japanese, at all events, have managed their medical and surgical departments.

Probably the best account we possess of the condition of the Japanese military hospitals is contained in a paper by Major L. L. Seaman, late Surgeon, U.S. Vol. Engineers, published in the Journal of the Association of Military Surgeons for January, 1905. He gives a full account, of the Red Cross and University Hospitals at Tokio, and speaks highly of all the sanitary arrangements, except the latrines, which are earth closets and antiquated. He found that as a rule no operations were performed at the front, only first aid given and the wounded sent off to the base as soon as possiblemany cases had healed by the time of their arrival. He also visited the reserve hospitals at Hiroshima on the Inland Sea, which consisted of six divisions with ten corridor wards in each. He noted the constant flooding of floors of operating and dressing rooms with bichloride. He found that the high velocity bullets at short range acted as if explosive ones. Spurious and traumatic aneurysms were frequent, arising from injury to the vascular walls by passage of bullets over them. There were many penetrating wounds of the great cavities, but they mostly did well, the apertures healing under first aid. He was also much struck by the small number of medical cases and the absence of intestinal complaints, etc. which he attributed to the diet of the Japanese soldier-nothing to clog the bowels, which they are taught to keep in good order. The Red Cross ships, which carry wounded from the front to base, will take 200 patients, and are furnished with operating and radiography rooms.

He also visited Simonosaki, which is the base hospital for the navy. Here the wounds were mostly caused by shellvery few bullet wounds-but all the cases did well as a rule.

He draws three great lessons from the Japanese, the three great life-saving factors, namely, medical commissariat, transport, and rapid departure to the base.

He also remarks that the status of the medical officer is properly recognized by rank and emoluments.

Papers No. I and II, on the disposal of the wounded in a naval war, and on the collection and distribution of wounded in a modern cruiser, open up a fruitful source of discussion, as these are subjects which the progress of the SpanishAmerican and Jap-Russian naval wars have brought under our notice. Inspector-General Belgrave Ninnis, who was President of this Section in 1902, contributed an address in which he ably sketched a plan for dealing with wounded during an action. This was based on the use of hospital ships in attendance on the fleet, on to which sick and wounded could be transferred at once. The arrangement of these ships was complete in his plan.

Dr. T. Cropper Wise, Medical Director U.S. Navy, in the 